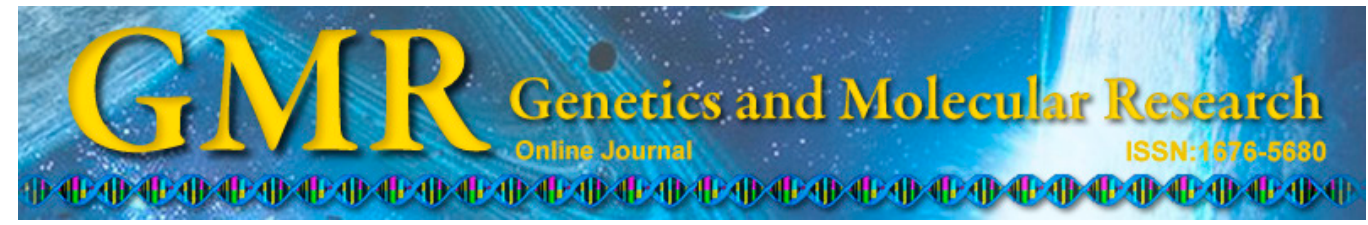

\title{
Meiotic behavior and chromosome number of Urochloa adspersa (Trin.) R. D. Webster from the Brazilian Chaco
}

\author{
M.F. Felismino ${ }^{1}$, R.L.S. Maior ${ }^{2}$, G.A. Damasceno Jr. ${ }^{1}$, A. Pott ${ }^{1}$ and \\ M.S. Pagliarini ${ }^{2 \dagger}$ \\ ${ }^{1}$ Departamento de Botânica, Universidade Federal de Mato Grosso do Sul, \\ Campo Grande, MS, Brasil \\ ${ }^{2}$ Departamento de Biologia Celular e Genética, \\ Universidade Estadual de Maringá, PR, Brasil \\ ${ }^{\dagger}$ In memoriam \\ Corresponding author: M.F. Felismino \\ E-mail: mariferrari82@gmail.com
}

Genet. Mol. Res. 14 (3): 7455-7462 (2015)

Received October 1, 2014

Accepted February 23, 2015

Published July 3, 2015

DOI http://dx.doi.org/10.4238/2015.July.3.21

\begin{abstract}
This is the first report of meiotic division in Urochloa adspersa (Trin.) collected from the Brazilian Chaco. Meiotic analyses were performed on three specimens of $U$. adspersa named G10, G15, and G16. Inflorescences were collected and fixed in a mixture of ethanol and acetic acid $(3: 1, \mathrm{v} / \mathrm{v})$ for $24 \mathrm{~h}$ and then stored in $70 \%$ alcohol. Diakinesis revealed different chromosome numbers and ploidy levels. All three plants were polyploids: G10 and G15
\end{abstract}


exhibited $2 \mathrm{n}=6 \mathrm{x}=54$ chromosomes (arranged in 27 bivalents), while G16 exhibited $2 \mathrm{n}=4 \mathrm{x}=36$ chromosomes (18 bivalents). Meiotic behavior was mainly normal in the hexaploid G15 and the tetraploid G16 (5.3 and 6.2\% of the cells were abnormal, respectively), revealing only a few meiotic abnormalities that are common to polyploids, i.e., those related to irregular chromosome segregation. G10 exhibited other meiotic abnormalities during meiosis II, such as chromosome stickiness, irregular spindle orientation, and irregular cytokinesis, which led to the formation of a few triads, resulting in $16.9 \%$ of the cells being abnormal. The origin of these abnormalities is discussed, and we suggest that the genes that control meiotic steps may be present in the Urochloa gene pool.

Key words: Microsporogenesis; Polyploidy; Native grass; Brachiaria; Chaco grass

\section{INTRODUCTION}

Chaco vegetation covers approximately $800,000 \mathrm{~km}^{2}$ of Argentina, Paraguay, and Bolivia, including the western edge of the Mato Grosso do Sul State in Brazil (Hueck, 1972). The Brazilian Chaco is in the municipality of Porto Murtinho, and is restricted to a narrow strip located between the Paraguay and Apa Rivers that is not easily identified and defined on regional-scale maps (Prado et al., 1992). Prado et al. (1992) stated that the vegetation of Porto Murtinho was the only one that could be considered true Chaco. However, during the last few decades half of the original vegetation of the Brazilian Chaco has been cleared (Silva et al., 2011), and most of this heterogeneous landscape has been converted to agricultural fields and pastures.

Poaceae is one of the largest and most important families of angiosperms because of its economic and ecological importance, and Brazil contains approximately 197 genera and 1368 species of this family (Longhi-Wagner et al., 2005). We consider the Poaceae to be the most representative family of herbaceous vegetation in the Chaco of Porto Murtinho (A. Pott and J.F.M. Valls, personal communication). Knowledge of the diversity and biology of these species, including chromosome number, represents a starting point for the characterization of the herbaceous vegetation of this environment and a significant contribution to our knowledge of the Chaco as a whole.

Urochloa adspersa (Trin.) R. D. Webster (synonym, Brachiaria adspersa (Trin.) Parodi) is native to South America, the West Indies, and the southeast of the USA (Seiffert, 1984; Morrone and Zuloaga, 1992), although in some regions it is considered naturalized (Shirasuna, 2013). There have only been a few cytogenetic studies conducted on this genus, most of which were on species of the genus Brachiaria (Miles et al., 1996; Karia et al., 2006; Valle and Pagliarini, 2009). Although many researchers use the name Brachiaria, we are following the taxonomic revision of Morrone and Zuloaga (1992).

This study investigated the meiotic behavior, chromosome numbers, and ploidy levels of $U$. adspersa specimens collected from different sites in the Brazilian Chaco. 


\section{MATERIAL AND METHODS}

Plants were collected from various sites in the Porto Murtinho municipality in March 2012: 1) Fazenda Santa Vergínia (22 $\left.01^{\prime} 12.5^{\prime \prime S}, 57^{\circ} 52^{\prime} 10.2^{\prime \prime W}\right)$; 2) Fazenda Retiro Conceição $\left(21^{\circ} 40^{\prime} 58.2^{\prime \prime S}, 57^{\circ} 46^{\prime} 44.2^{\prime \prime} \mathrm{W}\right)$; and 3) Fazenda Bala (21 $\left.{ }^{\circ} 41^{\prime} 42.4^{\prime \prime S}, 57^{\circ} 42^{\prime} 55.8^{\prime \prime} \mathrm{W}\right)$, and the three plants collected at these sites were named G10, G15, and G16, respectively. We conducted systematic walks over the collection sites and collected inflorescences for both taxonomic and cytogenetic studies. Specimens of the collected material were deposited in the CGMS Herbarium of Universidade Federal de Mato Grosso do Sul (UFMS) after identification. The inflorescences were fixed in a mixture of ethanol and acetic acid $(3: 1$, $\mathrm{v} / \mathrm{v})$ for $24 \mathrm{~h}$ and then stored in $70 \%$ alcohol. Cells undergoing microsporogenesis were analyzed by the squashing technique using $1 \%$ propionic carmine, and images were taken with a Leica DM5500B microscope (São Paulo, Brazil) and edited using the PhotoScape software (http://www.photoscape.org/).

\section{RESULTS}

Diakinesis revealed different chromosome numbers and ploidy levels. G10 and G15 exhibited 27 bivalents in all of the cells undergoing diakinesis (Figure 1a and b), while G16 exhibited a multivalent configuration ( 16 bivalents and one quadrivalent) in only one of the 38 cells analyzed, resulting in $97.4 \%$ of cells having 18 bivalents (Figure 1c and d). Therefore, the chromosome numbers were $2 \mathrm{n}=4 \mathrm{x}=36$ for G16 and $2 \mathrm{n}=6 \mathrm{x}=54$ for G10 and G15, with $\mathrm{x}=9$ as the basic chromosome number.

Meiosis was mainly normal in all of the specimens analyzed (Table 1; Figure 1e, g, i, and j). G10 exhibited the most abnormal meiosis, with $16.9 \%$ of cells being abnormal (Table 1). Abnormalities were observed in meiosis I and II, and consisted of precocious chromosome migration to the poles in metaphases I and II and laggard chromosomes in anaphases I (Figure 1h) and II, which led to the formation of micronuclei in telophases I and II. Some of these micronuclei persisted to tetrads and microspores, but at a very low frequency (Table 1). These abnormalities are common in polyploids, and confirm the polyploid status of the species. However, G15 and G16 exhibited nearly normal meiosis, with only 5.3 and $6.2 \%$, respectively, of cells being abnormal (Table 1).

One type of meiotic abnormality observed in the three plants was non-oriented bivalents at the equatorial plate during metaphase I (4.3, 4.2, and $25.3 \%$ for G10, G15, and G16, respectively; Figure 1f). Other meiotic abnormalities were only observed in G10, such as chromosome stickiness during prophase II (12.8\%), an irregular spindle during metaphase II (33.3\%), a lack of cytokinesis (observed in one cell) during anaphase II (14.3\%), and possible restitution nuclei (also observed in one cell) during telophase II (4.1\%; Figure $1 \mathrm{k})$, which probably originated from the spindle irregularity during metaphase II and could have been related to the observed triads (17.9\%; Figure 11) as a result of nucleus restitution. 
Table 1. Number and percentage (in parentheses) of normal cells per meiotic phase, types of abnormality observed per meiotic phase, and number and percentage (in parentheses) of abnormal cells in Urochloa adspersa G10, U. adspersa G15, and U. adspersa G16 from the Brazilian Chaco.

\begin{tabular}{|c|c|c|c|}
\hline Phase & $\begin{array}{l}\text { U. adspersa }(\mathrm{G} 10) \\
(2 \mathrm{n}=6 \mathrm{x}=54)\end{array}$ & $\begin{array}{l}\text { U. adspersa }(\mathrm{G} 15) \\
(2 \mathrm{n}=6 \mathrm{x}=54)\end{array}$ & $\begin{array}{l}\text { U. adspersa }(\mathrm{G} 16) \\
(2 \mathrm{n}=4 \mathrm{x}=36)\end{array}$ \\
\hline Metaphase I & $38(82.6)$ & $63(87.5)$ & $61(73.5)$ \\
\hline - precocious migration & $6(13.1)$ & $6(8.3)$ & $1(1.2)$ \\
\hline - non-oriented bivalent & $2(4.3)$ & $3(4.2)$ & $21(25.3)$ \\
\hline Anaphase I & $23(85.2)$ & $40(90.9)$ & $80(98.8)$ \\
\hline - laggards & $4(14.8)$ & $4(9.1)$ & $1(1.2)$ \\
\hline Telophase I & $45(97.8)$ & $45(97.8)$ & $60(100)$ \\
\hline - micronuclei & $1(2.2)$ & $1(2.2)$ & - \\
\hline Prophase II & $37(78.7)$ & $55(100)$ & $30(100)$ \\
\hline - micronuclei & $4(8.5)$ & - & - \\
\hline - chromosome stickiness & $6(12.8)$ & - & - \\
\hline Metaphase II & $8(53.4)$ & $6(100)$ & - \\
\hline - precocious migration & $2(13.3)$ & - & - \\
\hline - irregular spindle & $5(33.3)$ & - & - \\
\hline Anaphase II & $5(71.4)$ & - & $1(100)$ \\
\hline - laggards & $1(14.3)$ & - & - \\
\hline - lack of cytokinesis & $1(14.3)$ & - & - \\
\hline Telophase II & $22(91.7)$ & - & $4(100)$ \\
\hline - micronuclei & $1(4.2)$ & - & - \\
\hline - restitutional nuclei & $1(4.1)$ & - & - \\
\hline Tetrads & $21(75)$ & $10(100)$ & $83(94.3)$ \\
\hline - micronuclei & $2(7.1)$ & - & $5(5.7)$ \\
\hline - triads & $5(17.9)$ & - & - \\
\hline Microspores & $24(92.3)$ & 30 (100) & $152(98.1)$ \\
\hline - micronuclei & $2(7.7)$ & - & $3(1.9)$ \\
\hline Total number of cells & 266 & 263 & 502 \\
\hline Total number of abnormal cells & $45(16.9)$ & $14(5.3)$ & $31(6.2)$ \\
\hline
\end{tabular}

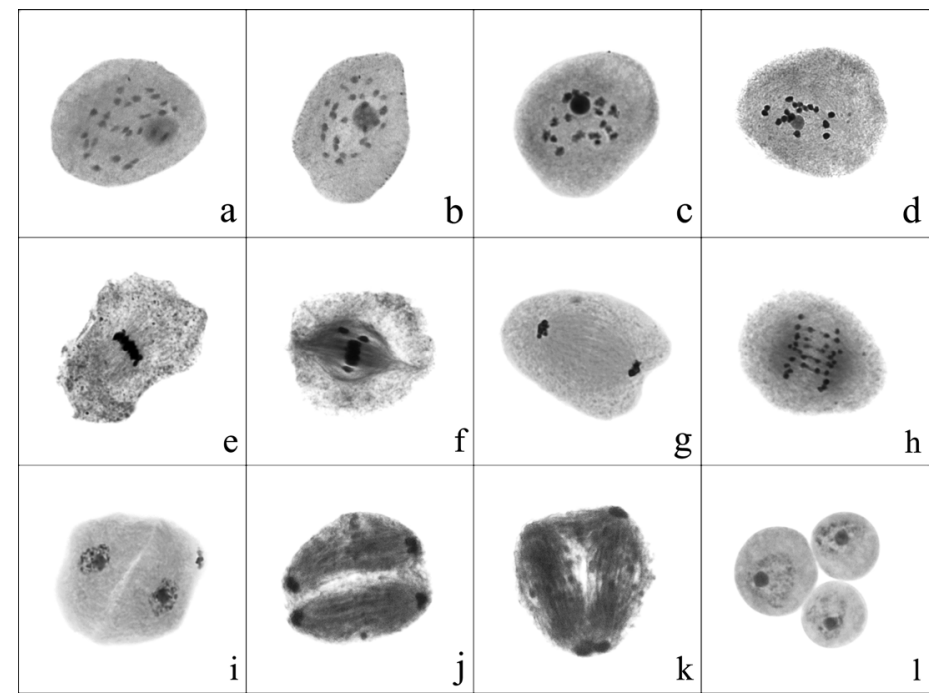

Figure 1. Meiosis in polyploidal Urochloa adspersa from the Brazilian Chaco (40X magnification). a. U. adspersa $\mathrm{G} 10(2 \mathrm{n}=6 \mathrm{x}=54)$ with 27 bivalents; b. $U$. adspersa $\mathrm{G} 15(2 \mathrm{n}=6 \mathrm{x}=54)$ with 27 bivalents; c. $U$. adspersa $\mathrm{G} 16(2 \mathrm{n}$ $=4 \mathrm{x}=36$ ) with 18 bivalents; d. $U$. adspersa G16 with 18 bivalents; e. Normal metaphase I in U. adspersa G16; f. Non-oriented bivalents in hexaploid U. adspersa; g. Normal anaphase in U. adspersa G16; h. Anaphase I with laggard chromosomes in $U$. adspersa G16; i. Prophase II in $U$. adspersa G16; j. Normal anaphase II in hexaploid $U$. adspersa; k. Telophase II with possible restitution nuclei in U. adspersa G10; l. Triad in U. adspersa G10. 


\section{DISCUSSION}

Morrone and Zuloaga (1992) revised the taxonomy of this group and classified several species into the genus Urochloa. We have decided to follow their taxonomic revision, based on taxonomic evidence from the collected specimens. There is much debate regarding the taxonomy of Brachiaria and Urochloa. Tórres-González and Morton (2005) conducted a phylogenetic study based on nucleotide-base sequence polymorphisms in the internal transcribed spacer region of nuclear ribosomal DNA, and were unable to separate Brachiaria from Urochloa. The classification of these species is still a matter of great discussion, but was not the focus of the present study.

Little is known about the cytology of the Urochloa grasses, despite their great number of species and agronomic and economic importance, and their broad distribution and use in the tropics. This is the first cytological report that has investigated meiotic behavior in $U$. adspersa in Brazil, specifically from the Brazilian Chaco. Morrone and Zuloaga (1992) reported that Argentine plants are polyploid, with $2 n=54$. The chromosome numbers of no more than 44 Brachiaria and/or Urochloa species have been reported; however, there have been few detailed studies of their karyotypic morphologies (Valle et al., 1987; Bernini and Marin-Morales, 2001). Many of the genus' species that have no agronomic interest, or are not included in active germplasm collections have not been cytologically studied.

Most angiosperms are polyploids, and polyploidy plays an important role in their evolutionary history (Leitch and Bennett, 1997; Meyers and Levin, 2006; Soltis et al., 2009). Polyploidy is very common in grasses, and according to Stebbins (1956) approximately 70\% of grasses exhibit polyploidy. Polyploidy also predominates in the genus Brachiaria, particularly tetraploidy (Letteriello et al., 1999; Mendes-Bonato et al., 2002a,b). Penteado et al. (2000) studied ploidy levels using flow cytometry in all Brachiaria accessions of economic importance that were maintained by Embrapa Beef Cattle (Campo Grande, MS, Brazil), and found a wide variation in ploidy levels between and within species, ranging from diploids to heptaploids. However, none of these studies included U./B. adspersa in their analyses.

Darlington and Wylie (1955) determined that $\mathrm{x}=7$ and $\mathrm{x}=9$ are the basic chromosome numbers in Brachiaria. The majority of researchers agree with these numbers. Recently, RissoPascotto et al. (2006) described $\mathrm{x}=6$ for $B$. dictyoneura. Our analyses reveal that $U$. adspersa is also a polyploid, with $2 n=4 x=36$ and $2 n=6 x=54$ chromosomes, derived from $x=9$. No multivalent formation was observed in the hexaploids G10 and G15, and a single quadrivalent configuration was observed during diakinesis in the tetraploid G16; the absence or a low frequency of multivalent formation suggests the occurrence of allopolyploidy. The low frequency of multivalent formation in tetraploidal $U$. adspersa suggests it could be a segmental allotetraploid, i.e., the parental genomes are only partially homologous (Stebbins, 1956).

Abnormal meiotic cells were observed in tetraploidal and hexaploidal $U$. adspersa at low frequencies (Table 1). Valle and Savidan (1996) reported that the natural diploids Brachiaria brizantha, Brachiaria decumbens, and Brachiaria ruziziensis exhibit regular meiosis, with chromosomes pairing in nine bivalents. Tetraploid forms, however, exhibit irregular meiosis, with univalents and quadrivalents being formed. The most common abnormalities found in polyploids are related to irregular chromosome segregation in both divisions: precocious chromosomes in metaphase plates and laggards in anaphases lead to the formation of micronuclei in telophases, which can lead to unbalanced pollen grains, affecting pollen fertility (Valle, 1986; Mendes-Bonato et al., 2001a,b; Junqueira-Filho et al., 2003; 
Utsunomiya et al., 2005). Few meiotic abnormalities were observed in the tetraploidal G16 and hexaploidal G10 and G15, and were related to irregular chromosome segregation (Table 1). One tetraploid access of Brachiaria humidicola exhibits regular meiosis, with 18 bivalents during diakinesis and sexual reproduction (Valle and Glienke, 1991), but other tetraploid accessions exhibit irregular meiosis (Valle, 1986). Brachiaria mutica and Brachiaria arrecta are tetraploidal species; the first exhibits irregular chromosome pairing and reproduction by apomixis, and the latter exhibits fairly regular bivalent pairing and sexual reproduction (Valle, 1986). Risso-Pascotto et al. (2009a) observed meiotic abnormalities at a low frequency in two hexaploid accessions of Brachiaria dura, as well as a few multivalent chromosome associations at diakinesis, and suggested that hexaploidy probably resulted from chromosome doubling. The accumulated evidence from several studies on Brachiaria point to an association between polyploidy and apomixis, with irregular meiosis, on the one hand, and sexual reproduction and regular chromosome pairing on the other (Valle and Savidan, 1996; Valle and Pagliarini, 2009). Valle and Pagliarini (2009) reported the modes of reproduction of many Brachiaria accessions, including one of $B$. adspersa, which reproduces sexually.

The presence of non-oriented bivalents at the equatorial plate was observed in G10, G15, and G16 (4.3, 4.2, and 25.3\%, respectively). Non-oriented bivalents can occur due to chromosomes being unable to attach to the equatorial plate. This may be related to the kinetochore. Factors that could prevent the attachment of the spindle fibers to the kinetochore were discussed by Nicklas and Ward (1994). These bivalents can be incorporated (or not) into the telophase nucleus. If incorporated, one of the telophase I nuclei would have one extra chromosome, and the other would have a missing chromosome, generating two microspores: $\mathrm{n}+1$ and $\mathrm{n}-1$, respectively. If they are not incorporated and originate microspores, both telophase I nuclei would have one missing chromosome, generating four aneuploid microspores ( $\mathrm{n}-1)$. Regardless of the non-oriented bivalent behavior, aneuploid gametes would be formed (Pagliarini, 2001).

Other abnormalities observed in the hexaploid G10 were related to chromosome stickiness during prophase II (12.8\%), a defective spindle during metaphase II (33.3\%), and a lack of cytokinesis during anaphase II (14.3\%), which could have resulted in the few triads observed (17.9\%). Chromosome stickiness is related to intense chromatin clustering, which can begin during pachytene and continue to metaphase I. At anaphase I, chromosomes form bridges that can be broken by mechanical forces, producing several chromatin fragments. Gaulden (1987) postulated that chromosome stickiness results from the defective behavior of one or two types of specific non-histone proteins involved in chromosome organization. Chromosome stickiness has been observed in several Brachiaria accessions and hybrids (Utsunomyia et al., 2005; Mendes-Bonato et al., 2001b, 2007; Risso-Pascotto et al., 2009b; Felismino et al., 2010; Ricci et al., 2011).

Risso-Pascotto et al. (2003) and Gallo et al. (2007) analyzed penta-, tetra-, and hexaploidal species of Brachiaria, and observed that a lack of, or abnormal, cytokinesis favored the rejoining of nuclei (restitutional nucleus) and the formation of monads, dyads, and triads, and consequently $2 \mathrm{n}$ gametes. Although polyploidy is common in Brachiaria its origin is still unknown, but $2 \mathrm{n}$ gametes could be a source of polyploidization.

The observation that these types of abnormalities occur in several Brachiaria species indicate that the genes controlling these meiotic steps are also present in the Urochloa gene pool, and if so, could also be present in $U$. adspersa. Cytological studies are important for providing information on the basic biology of species, from their chromosome numbers and ploidy levels to their evolutionary history, and even their population genetics and distribution 
patterns. We intend to study other Chaco species, since few studies have been conducted on the native vegetation of this biome. The Brazilian Chaco is very important and almost unknown, but human activity is becoming more intense and there is great risk of biome degradation, and consequently a loss of biodiversity.

\section{ACKNOWLEDGMENTS}

The authors are grateful to the Coordenação de Aperfeiçoamento de Pessoal de Nível Superior (CAPES) for financial support, and to D. Araújo of the Universidade Federal de Mato Grosso do Sul (UFMS) for commenting on the manuscript.

\section{REFERENCES}

Bernini C and Marin-Morales MA (2001). Karyotype analysis in Brachiaria (Poaceae) species. Cytobios 104: 157-171. Darlington CD and Wylie AP (1955). Chromosome atlas of flowering plants. Allen and Unwin, London.

Felismino MF, Pagliarini MS and Valle CB (2010). Meiotic behavior of interspecific hybrids between artificially tetraploidized sexual Brachiaria ruziziensis and tetraploid apomictic B. brizantha (Poaceae). Sci. Agric. 67: 191-197.

Gallo PH, Micheletti PL, Boldrini KR, Risso-Pascotto C, et al. (2007). 2n gamete formation in the genus Brachiaria (Poaceae: Paniceae). Euphytica 154: 255-260.

Gaulden ME (1987). Hypothesis: some mutagens directly alter specific chromosomal proteins (DNA topoisomerase II and peripheral proteins) to produce chromosome stickiness, which causes chromosome aberrations. Mutagenesis 2: 357-365.

Hueck K (1972). As regiões de matas do Chaco e áreas marginais. In: As florestas da América do Sul: Ecologia, Composição e Importância Econômica. Editora Polígono, Brasília, 240-275.

Junqueira-Filho RG, Mendes-Bonato AB, Pagliarini MS, Bione NCP, et al. (2003). Absence of microspore polarity, symmetric divisions and pollen cell fate in Brachiaria decumbens (Gramineae). Genome 46: 83-86.

Karia CT, Duarte JB and Araújo ACG (2006). Desenvolvimento de cultivares do gênero Brachiaria (Trin.) Griseb. no Brasil. Embrapa Cerrados, Planaltina.

Leitch IJ and Bennett MD (1997). Polyploidy in angiosperms. Trends Plant Sci. 2: 470-476.

Letteriello G, Valle CB, Christiane D and Penteado MIO (1999). Citologia e modo de reprodução de acessos pentaploides de B. brizantha. In: Proceedings of the Sociedade Brasileira de Zootecnia. Brazil, 36, SBZ, 140: 77.

Longhi-Wagner HM, Boldrini II and Boechat SC (2005). Morfologia e taxonomia de gramíneas sul-riograndenses. Editora da UFRGS, Porto Alegre.

Mendes-Bonato AB, Pagliarini MS, Silva N and Valle CB (2001a). Meiotic instability in invader plants of signal grass Brachiaria decumbens Stapf (Gramineae). Acta Sci. 23: 619-625.

Mendes-Bonato AB, Pagliarini MS, Valle CB and Penteado MIO (2001b). A severe case of chromosome stickiness in pollen mother cells of Brachiaria brizantha (Hochst) Stapf (Gramineae). Cytologia 66: 287-291.

Mendes-Bonato AB, Junqueira-Filho RG, Pagliarini MS, Valle CB, et al. (2002a). Unusual cytological patterns of microsporogenesis in Brachiaria decumbens: abnormalities in spindle and defective cytokinesis causing precocious cellularization. Cell Biol. Int. 26: 641-646.

Mendes-Bonato AB, Pagliarini MS, Forli F, Valle CB, et al. (2002b). Chromosome numbers and microsporogenesis in Brachiaria brizantha (Gramineae). Euphytica 125: 419-424.

Mendes-Bonato AB, Pagliarini MS and Valle CB (2007). Meiotic arrest compromises pollen fertility in an interspecific hybrid between Brachiaria ruziziensis x Brachiaria decumbens (Poaceae: Paniceae). Braz. Arch. Biol. Technol. 50: 831-837.

Meyers LA and Levin DA (2006). On the abundance of polyploids in flowering plants. Evolution 60: 1198-1206.

Miles JW, Maass BL and Valle CB (1996). Biology, agronomy, and improvement. CIAT, Colombia/Embrapa, Brazil.

Morrone O and Zuloaga FO (1992). Revision de las especies sudamericanas nativas e introducidas de los generos Brachiaria y Urochloa (Poaceae: Panicoideae: Paniceae). Darwiniana 31: 43-109.

Nicklas RB and Ward SC (1994). Elements of error correction in mitosis: microtubule capture, release and tension. J. Cell Biol. 125: 1241-1253.

Pagliarini MS (2001). Citogenética aplicada ao melhoramento. In: Recursos genéticos e melhoramento (Nass L, Valois ACC, Melo IS and Valadares-Inglis MC, eds.). Fundação MT, Rondonópolis, 872-910.

Penteado MIO, Santos ACM, Rodrigues IF, Valle CB, et al. (2000). Determinação de ploidia e quantidade de DNA em 
diferentes espécies do gênero Brachiaria. Boletim de Pesquisa 11, Embrapa Gado de Corte, Campo Grande.

Prado DE, Gibbs PE, Pott A and Pott VJ (1992). The Chaco-Pantanal transition in southern Mato Grosso, Brazil. In: Nature and dynamics of forest-savanna boundaries. (Furley PA, Proctor J and Ratter JA, eds.). Chapman and Hall, London, 451-470.

Ricci GCL, Souza-Kaneshima AM, Felismino MF, Mendes-Bonato AB, et al. (2011). Chromosome numbers and meiotic analysis in the pre-breeding of Brachiaria decumbens (Poaceae). J. Genet. 90: 289-293.

Risso-Pascotto C, Pagliarini MS, Valle CB and Mendes-Bonato AB (2003). Chromosome number and microsporogenesis in a pentaploid accession of Brachiaria brizantha (Gramineae). Plant Breed. 122: 136-140.

Risso-Pascotto C, Pagliarini MS and Valle CB (2006). A new basic chromosome number for the genus Brachiaria (Poaceae: Panicoideae: Paniceae). Gen. Res. Crop Evol. 53: 7-10.

Risso-Pascotto C, Pagliarini MS and Valle CB (2009a). Chromosome number and microsporogenesis of two accessions of Brachiaria dura Stapf (Poaceae). Biota Neotrop. 9: 257-261.

Risso-Pascotto C, Pagliarini MS and Valle CB (2009b). Microsporogenesis in Brachiaria bovonei (Chiov.) Robyns and $B$. subulifolia (Mez) Clayton (Poaceae). Sci. Agric. 66: 691-696.

Seiffert NF (1984). Gramíneas forrageiras do gênero Brachiaria. Circular Técnica, I. Reimpressão. EMBRAPA-CNPGC, Campo Grande.

Shirasuna RT (2013). Urochloa in Lista de Espécies da Flora do Brasil. Jardim Botânico do Rio de Janeiro. Available at [http://floradobrasil.jbrj.gov.br/jabot/floradobrasil/FB20518]. Accessed October 7, 2013.

Silva JSV, Pott A, Abdon MM, Pott VJ, et al. (2011). Projeto GeoMS: cobertura vegetal e uso da terra do Estado de Mato Grosso do Sul. Embrapa Informática Agropecuária, Campinas.

Soltis DE, Albert VA, Leebens-Mack J, Bell CD, et al. (2009). Polyploidy and angiosperm diversification. Am. J. Bot. 96: 336-348.

Stebbins GL (1956). Cytogenetics and evolution of the grass family. Am. J. Bot. 43: 891-905.

Tórres-González AM and Morton CM (2005). Molecular and morphological phylogenetic analysis of Brachiaria and Urochloa (Poaceae). Mol. Phylogenet. Evol. 37: 36-44.

Utsunomiya KS, Pagliarini MS and Valle CB (2005). Microsporogenesis in tetraploid accessions of Brachiaria nigropedata (Ficalho \& Hiern) Stapf (Gramineae). Biocell 29: 295-301.

Valle CB (1986). Cytology, mode of reproduction, and forage quality of selected species of Brachiaria Griseb. Doctoral thesis, University of Illinois, Urbana.

Valle CB and Glienke C (1991). New sexual accessions in Brachiaria. Apomixis Newslett. 3: 11-13.

Valle CB and Savidan YH (1996). Genetics, cytogenetics, and reproductive biology of Brachiaria. In: Brachiaria: Biology, agronomy, and improvement (Miles JW, Maass BL and Valle CB, eds.). CIAT/EMBRAPA-CNPGC, Calli/ Brasília, 147-163.

Valle CB and Pagliarini MS (2009). Biology, cytogenetics, and breeding of Brachiaria. In: Genetic resources, chromosome engineering, and crop improvement (Singh RJ, ed.). CRC Press, Boca Raton, 103-151.

Valle CB, Singh RJ and Miller DA (1987). Pachytene chromosomes of Brachiaria ruziziensis Germain et Evrard. Plant Breed. 98: 75-78. 